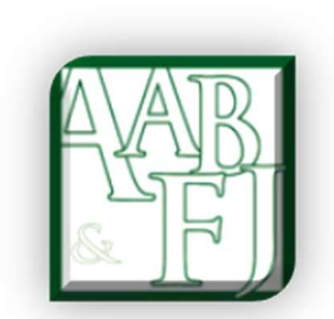
\title{
Stock Prices: an Analysis of the Symmetric and Asymmetric Effect Using ARDL and NARDL Models
}

Exchange Rate, Exchange Rate Volatility and

\author{
La Ode Saidi', Abd Azis Muthalib ${ }^{2}$, Pasrun Adam³, Wali Aya Rumbia ${ }^{4}$, La Ode Arsad \\ Sani $^{5}$
}

\begin{abstract}
This article examined the symmetric and asymmetric effects of the IDR/USD exchange rate and its volatility on stock prices using the monthly time series data of the IDR/USD exchange rate and the Indonesian composite stock price index from January 2006 to July 2019. The data were analyzed using ARDL and NARDL models. The results showed that in the short term, the IDR/USD exchange rate has a symmetry effect on stock prices, while volatility lacks such a symmetric influence. However, these two variables asymmetrically affect stock prices, Furthermore, in the long term both the exchange rate and the volatility lack symmetric and asymmetric influence on stock prices.
\end{abstract}

JEL classification: C13, E44, F31, F33

Keywords: Exchange rate, exchange rate volatility, stock prices, ARDL model, NARDL model.

\footnotetext{
${ }^{1}$ Universitas Halu Oleo, Kendari 93232, Indonesia, E-mail: laode.saidi@uho.ac.id

${ }^{2}$ Universitas Halu Oleo, Kendari 93232, Indonesia, E-mail: azismuthalib@uho.ac.id

${ }^{3}$ Universitas Halu Oleo, Kendari 93232, Indonesia, E-mail: pasrun.adam@uho.ac.id

${ }^{4}$ Universitas Halu Oleo, Kendari 93232, Indonesia, E-mail: waliaya.rumbia@uho.ac.id

${ }^{5}$ Universitas Halu Oleo, Kendari 93232, Indonesia. E-mail: arsadni@yahoo.com
} 


\section{INTRODUCTION}

In the global economy, foreign currency is used for international trading both in the real and financial sectors (Saidi et al., 2015; Adam et al., 2017). International trade may increase demand for foreign currency, which, in turn, change currency rates. Regarding investments, foreign currencies are traded in the financial markets. This allows investors to purchase and sell their currencies, leading to adjustments and volatility of exchange rates. According to Ma and Kao (1990), exchange rate volatility is on an upward trend from early 1970s and can impact stock prices. This has attracted studies on the relationship between exchange rate volatility and stock prices.

Ma and Kao (1990) and Dornbush and Fisher (1980) established theories on one-way causal relationships from exchange rates to stock prices. Ma and Kao (1990) developed a mathematical model involving variables of exchange rates as well as foreign and domestic stocks. While developing this model, it was assumed that only foreign and domestic stocks were traded in the market. The econometric test showed that in a dominant country in exports, currency appreciation reduces export competitiveness and negatively affects domestic stock prices. Conversely, in a country with a greater dominance over imports, currency appreciation lowers import costs, which positively affects stock prices. Dornbush and Fisher (1980) developed a theory of the goods market. The theory states that exchange rate changes affect a company's profits through import and export activities in the goods market. Such profits will ultimately affect stock prices. In investment portfolios, exchange risk is measured by exchange rate volatility. Importantly, an increased exchange rate volatility may influence investors' attitudes in choosing financial assets as part of their investment portfolios, raising the stock demand and prices (Wagner, 2019).

Empirical studies regarding the exchange rate effects on stock prices were conducted in different nations (Malliaropulos, 1998; Mgammal, 2012; Suriani et al., 2015). However, the findings of these studies have been inconsistent, probably due to two main factors. First, the researched countries' economic and socio-political conditions and cultural characteristics vary (Ozturk, 2010). Second, each of these studies used a distinct time-series data period (Novita and Nachrowi, 2005; Adam et al., 2015). The exchange rate volatility impact on stock prices has also been researched. Notable studies include Bag et al. (2017) and Mechri et al. (2018), while the asymmetric effect on stock prices were also investigated by others, including Bahmani-Oskooee and Saha (2016), and Merchri et al. (2018). Table 1 summarizes all the research mentioned above are summarized.

Several researches examined the symmetric and asymmetric effects of exchange rates on stock prices. However, studies on asymmetric effects are still scarce. Bahmani-Oskooee and Saha (2016) is the only research that investigated such an effect in Indonesia using a non-linear panel ARDL model for data analysis, whereas, this study used a non-linear ARDL. The question arises as to whether the exchange rate and its volatility have symmetric and asymmetric effects on stock prices in certain countries like Indonesia. This question is essential to address, primarily because none of the previous works has focused on the asymmetric impact of exchange rate volatility on stock prices in Indonesia, which is the focus of this research.

This research investigates the symmetric and asymmetric impacts of exchange rate and volatility on stock prices with monthly data from January 2006 to July 2019. It supplements economic literature on the symmetric and asymmetric impacts of these variables on stock prices as well as the use of ARDL and nonlinear ARDL. Specifically, the ARDL and nonlinear ARDL help determine the symmetry and asymmetric influences of these two variables, respectively. 
Table 1: Summary of Relevant Previous Studies

\begin{tabular}{|c|c|c|c|c|}
\hline Author (Year) & Variable & lysis model & Period/Country & Results \\
\hline \multicolumn{5}{|l|}{ Symmetry effect: } \\
\hline Malliaropulos (1998) & $\begin{array}{l}\text { Exchange rate, stock } \\
\text { price }\end{array}$ & Panel data & $\begin{array}{l}\text { 1973:1-1992:3, } \\
\text { OECD Countries }\end{array}$ & $\begin{array}{l}\text { The exchange rate } \\
\text { negatively affected } \\
\text { stock prices }\end{array}$ \\
\hline Mgammal (2012) & $\begin{array}{l}\text { Exchange rate, interest } \\
\text { rate, inflasi, the stock } \\
\text { price }\end{array}$ & $\begin{array}{l}\text { Linear } \\
\text { regression }\end{array}$ & $\begin{array}{l}2008.1-2009.12 \text {, } \\
\text { Saudi Arabia and } \\
\text { the UEA }\end{array}$ & $\begin{array}{l}\text { The exchange rate } \\
\text { positively affected } \\
\text { stock prices }\end{array}$ \\
\hline Suriani et al. (2015). & $\begin{array}{l}\text { Exchange rate, the stock } \\
\text { price }\end{array}$ & $\begin{array}{l}\text { Granger } \\
\text { causality }\end{array}$ & $\begin{array}{l}\text { 2004.1-2009.12; } \\
\text { Pakistan }\end{array}$ & $\begin{array}{l}\text { The exchange rate did } \\
\text { not affect stock prices }\end{array}$ \\
\hline Bag et al. (2017) & $\begin{array}{l}\text { Exchange rate volatility, } \\
\text { the stock price }\end{array}$ & $\begin{array}{l}\text { Simple linear } \\
\text { regression }\end{array}$ & $\begin{array}{l}\text { 2003.1-2015.12, } \\
\text { Pakistan }\end{array}$ & $\begin{array}{lr}\text { Exchange } & \text { rate } \\
\text { volatility had } & \text { a } \\
\text { positive effect } & \text { on } \\
\text { stock prices } & \end{array}$ \\
\hline Mechri et al. (2018) & $\begin{array}{l}\text { Exchange rate volatility, } \\
\text { inflation rate, interest } \\
\text { rate, the stock price }\end{array}$ & $\begin{array}{l}\text { Linear } \\
\text { regression } \\
\text { multiple }\end{array}$ & $\begin{array}{l}\text { 2002:1-2017:1, } \\
\text { Turkey and Tunisia }\end{array}$ & $\begin{array}{l}\text { Exchange rate } \\
\text { volatility positively } \\
\text { affected stock prices }\end{array}$ \\
\hline \multicolumn{5}{|l|}{ Asymmetrical effect: } \\
\hline $\begin{array}{l}\text { Bahmani-Oskooee } \\
\text { and Saha (2016) }\end{array}$ & $\begin{array}{l}\text { The partial sum of } \\
\text { positive and negative } \\
\text { changes in the exchange } \\
\text { rate and rate stock price }\end{array}$ & $\begin{array}{l}\text { Non-linear } \\
\text { ARDL }\end{array}$ & $\begin{array}{l}\text { 1973-2015, } \\
\text { Canada, Brazil, } \\
\text { Chile, } \\
\text { Indonesia, Kapan, } \\
\text { Mexico, Malaysia } \\
\text { and the U. K }\end{array}$ & $\begin{array}{l}\text { The exchange rate } \\
\text { had an asymmetric } \\
\text { impact on stock } \\
\text { prices }\end{array}$ \\
\hline $\begin{array}{l}\text { Azarbayjani et al. } \\
(2018)\end{array}$ & $\begin{array}{l}\text { The partial sum of } \\
\text { positive and negative } \\
\text { changes in the exchange } \\
\text { rate, interest rate, real } \\
\text { liquidity, consumer price } \\
\text { index, the stock price }\end{array}$ & $\begin{array}{l}\text { Non-linear } \\
\text { ARDL }\end{array}$ & $\begin{array}{l}\text { 2001.1-2017/3, } \\
\text { Iran }\end{array}$ & $\begin{array}{l}\text { The exchange rate } \\
\text { had an asymmetric } \\
\text { effect on stock prices. }\end{array}$ \\
\hline
\end{tabular}

Section two of these research discusses the literature review, while the third one focuses on data and method. The fourth and the fifth sections are the findings, discussion and conclusion.

\section{LITERATURE REVIEW}

The value of currency between countries is referred to as exchange rate and change from the previous term to the current one is the exchange rate return in the investment context, while volatility is the standard deviation from variations in the exchange rate (Misra, 2018). In this subsection, several empirical studies of the symmetric and asymmetric effects of the exchange rate on stock prices are reviewed. It begins with the classification of these studies into three groups, including the effect of the exchange rate and volatility on stock prices. The study also classifies the asymmetric effect between these two variables. Importantly, the term effect in groups 1 and 2 is also called the symmetric effect.

Researches that belong to the first group include Ozbey et al. (2016), which investigated the impact of the TRY/USD exchange rate on stock prices in Turkey with monthly data from January 2009 to November 2015. The test results using the GARCH model indicated the 
relationship between two variables. Furthermore, Ozbey et al. (2016) investigated the impact of the relationship between these variables in Turkey with monthly data from January 2009 to November 2015. The test results using the GARCH model indicated the influence of exchange rate on stock prices. Lastly, Gong and Dai (2017) studied influence of interest rate and the exchange rate of CNY/USD on China's stock prices using daily data from 21 July 2005 to 31 June 2016. The effect was assessed using nonlinear regression model of Chang et al. (2000). The results indicated that stock price is influenced by interest and exchange rates.

In the second group, several researches examined the relationship between these variables, including Olugbenga (2012), Mlambo et al. (2013), Parera (2016), Sichoongwe (2016), Najafzadeh et al. (2016) and Mrhari and Dadoui (2017). The long term and short term effects of the Naira/USD exchange rate volatility on Nigeria's stock prices was investigated by Olugbenga (2012) using monthly data from 1985-2009. Granger causality test results showed a short term and long term effect of exchange rate. The volatility of currency rates against South Africa's stock prices was investigated by Mlambo et al. (2013) using the GARCH model. The econometric test results on monthly data for the 2000-2010 period showed that exchange rate volatility negatively affected stock prices or stock market capitalization. Parera (2016) investigated the effect of exchange rate volatility on India's stock market returns using data from January 2010 to December 2015. The data was analyzed using the GARCH model. The analysis results showed a positive impact of the euro exchange rate volatility on stock returns. However, the USD exchange rate volatility and the British Pound exchange rate did not affect stock price returns. The study suggested that investors need to consider the exchange rate volatility in their investment decision making. Sichoongwe (2016) examined the exchange rate volatility of share prices in Zambia. An analysis of annual data from 2000 to 2015 using the GARCH model indicated that exchange rate volatility negatively influenced stock prices. The proposed policy implication was that exchange rate movement needed to be stabilized to attract foreign portfolio investment. Najafzadeh et al. (2016) researched exchange rate volatility influence on stock returns in the D8 countries (Iran, Pakistan, Bangladesh, Indonesia, Malaysia, Egypt, Nigeria, and Turkey). The results of the PanelGARCH model test on monthly data from January 2008 to June 2016 showed the effect of exchange rate volatility on stock returns only in Pakistan, Indonesia, and Bangladesh. Mrhari and Dadoui (2017) examined the effect of exchange rate volatility on stock prices in Marocco. The VECM test on the data showed that exchange rate volatility affected stock prices.

The third group include Saman (2015) and Luqman and Kouser (2018). The asymmetric relationship between the exchange rate and stock prices in Romania was investigated by Saman (2015) using monthly data from March 2000 to March 2014. The test results on the data using the TAR-ECM and MTAR-ECM revealed the exchange rate has an asymmetric effect on stock prices in the long term and short term. Luqman and Couser (2018) investigated the asymmetric effect of exchange rates on stock market prices from G8 +5 countries (Brazil, Canada, China, France, Germany, India, Italy, Japan, Mexico, Russia, South Africa, UK, USA) as well as Pakistan using annual data for the 2000-2016 period. The econometric test results through the NARDL model showed the exchange rate has an asymmetric influence on the stock price.

\section{DATA AND METHOD}

\subsection{Data}

Time-series data concerning the composite stock price index and exchange rate, specifically the monthly data from January 2006 to July 2019 were used in this research. The composite stock price index represented the stock prices. Similarly, the IDR/USD exchange rate 
proxied exchange rates because the US currency is often used in intercontinental trade. In the analysis, a time series of exchange rate volatility developed from the IDR/USD exchange rate time series using the GARCH model was utilized. Fusion Media Limited provided the required data.

\subsection{Method}

The autoregressive distributed lag (ARDL) model by Pesaran and Shin (1999) and Heij et al. (2004) was used to test the symmetric effect of the IDR/USD (EXR) exchange rate on stock prices (STP). ARDL models with time lag $\mathrm{p}$ and $\mathrm{q}$, written as ARDL (p, q, r), are as follows.

$S T P_{t}=C_{1}+\sum_{i=1}^{p} \alpha_{i} S T P_{t-i}+\sum_{j=0}^{q} \beta_{j} E X R_{t-j}+\sum_{k=0}^{r} \gamma_{k} E X V_{t-k}+\varepsilon_{1 t}$

Where $C_{1}$ is the intercept, $\alpha_{i}(i=1,2, \ldots, p), \beta_{j}(j=0,1, \ldots, q)$ and $\gamma_{k}(k=0,1, \ldots, r)$ are the coefficients of the variable, and $\varepsilon_{1 t}$ is an error that is homoscedastic and has no autocorrelation. EXR and STP variables are logarithmic forms, while EXV is the exchange rate volatility, a measure of risk (Mishra, 2018). In model (1), the volatility $E X V=\sqrt{h_{t}}$ which is constructed using the GARCH(1,1) model in (2) as stated by Bahmani-Oskooee and Xi (2015), namely

$E X R=C_{2}+E X R_{t-1}+\varepsilon_{2 t}$

$h_{t}=w+\alpha h_{t-1}+\beta \varepsilon_{2(t-1)}$

(ECM).

Equation (1) can be changed to equation (3), hereinafter called error correction model

$$
\begin{aligned}
D\left(S T P_{t}\right)= & \beta_{0} D\left(E X R_{t}\right)+\gamma_{0} D\left(E X V_{t}\right)+\Pi_{1} E C_{1(t-1)}+\sum_{i=1}^{p-1} \alpha_{i}{ }^{*} S T P_{t-i} \\
& +\sum_{j=1}^{q-1} \beta_{j}{ }^{*} E X R_{t-j}+\sum_{k=1}^{r-1} \gamma_{k}{ }^{*} E X V_{t-k}+\varepsilon_{1 t}
\end{aligned}
$$

where $\Pi_{1}$ is called the error correction coefficient leading to the equilibrium condition, and the error correction variable $E C_{1(t-1)}$ satisfies equation (4). The coefficients $\beta_{0}, \gamma_{0}, \alpha_{i}{ }^{*}, \beta_{j}{ }^{*}$ and $\gamma_{k}{ }^{*}$ are short term multipliers of $D\left(S T P_{t}\right)$

$E C_{1(t-1)}=S T P_{t-1}-\frac{\sum_{j=0}^{q} \beta_{j}}{1-\sum_{i=1}^{p} \alpha_{i}} E X R_{t-1}-\frac{\sum_{j=0}^{r} \gamma_{j}}{1-\sum_{i=1}^{p} \alpha_{i}} E X V_{t-1}-\frac{C_{1}}{1-\sum_{i=1}^{p} \alpha_{i}}$

where $\left(\frac{\sum_{j=0}^{q} \beta_{j}}{1-\sum_{i=1}^{p} \alpha_{i}}, \frac{\sum_{j=0}^{r} \gamma_{j}}{1-\sum_{i=1}^{p} \alpha_{i}}\right)$ is the vector of a long term multiplier. If EXR, EXV and STP are not cointegrated, then equation (3) will be the ARDL (p-1, q-1, r-1) equation at first difference. In this case, the term $\Pi_{1} E C_{1(t-1)}$ is omitted.

In estimating the ARDL model, the following steps were followed. The stationarity of EXR, EXV and STP variables were first tested. The stationarity test is also called the unit root test or integration order test. The Augmented Dickey-Fuller (ADF) test put forward by Dickey and Fuller (1979) and the Phillips-Peron (PP) by Phillips and Peron (1988) were used to determine the stationarity of the variables. The null hypothesis of both stasionary tests is the time series has a unit root. Afterward, the cointegration between EXR, EXV and STP was examined. The test is performed in case the variables are stationary at the first difference or integrated of order 1, I (1). The Engle-Granger and Phillips-Ouliaris cointegration tests proposed by Engle and Granger (1987) and Phillips and Ouliaris (1990) are used when all of them are stationary at the first difference. The null hypothesis of both cointegration tests is the three-time series EXR, EXV and STP, which are not cointegrated. The three-time series EXR, EXV and STP cointegrate in case the residual $R E S_{1}=E C_{1}$ in equation (4) is stationary at the level. The Engle-Granger cointegration test 
follows the ADF test procedure. In comparison, the Phillips-Ouliaris cointegration test follows the PP test procedure. Subsequently, the regression parameters were estimated and interpreted.

The NARDL model was employed to test the asymmetric effect of exchange rates and volatility on stock prices. Essentially, the NARDL is the development of the ARDL proposed by Shin et al. (2014). It involves four variables covering the partial sum of positive changes in exchange rates (ERP), the partial sum of negative changes in exchange rates (ERN), the partial sum of positive changes in exchange rate volatility (EVP), and the partial sum of negative changes in exchange rate volatility (EVN). ERP and ERN are referred to as depreciation and appreciation of currency. The four variables of ERP, ERN, EVP, and EVN are defined as follows.

$E R P_{t}=\sum_{i=1}^{t} \max \left[\Delta E X R_{i}, 0\right]=\sum_{i=1}^{t} \max \left[D\left(E X R_{i}\right), 0\right]$

$E R N_{t}=\sum_{i=1}^{t} \min \left[\Delta E X R_{i}, 0\right]=\sum_{i=1}^{t} \min \left[D\left(E X R_{i}\right), 0\right]$

$E V P_{t}=\sum_{i=1}^{t} \max \left[\Delta E X V_{i}, 0\right]=\sum_{i=1}^{t} \max \left[D\left(E X V_{i}\right), 0\right]$

$E V N_{t}=\sum_{i=1}^{t} \min \left[\Delta E X V_{i}, 0\right]=\sum_{i=1}^{t} \min \left[D\left(E X V_{i}\right), 0\right]$

where $\quad D\left(E X R_{i}\right)=\Delta E X R_{i}=E X R_{i}-E X R_{i-1}=E X R-E X R(-1), i=1,2, \ldots, t \quad$ are $\quad$ the exchange rate change.

The NARDL $\left(\mathrm{p}, q_{1}, q_{2}, r_{1}, r_{2}\right)$ model that shows a one-way asymmetric correlation between the exchange rate and volatility on stock price is

$$
\begin{aligned}
S T P_{t}= & C_{3}+\sum_{i=1}^{p} \theta_{i} S T P_{t-i}+\sum_{j=0}^{q_{1}} \vartheta_{j} E R P_{t-j}+\sum_{k=0}^{q_{2}} \varphi_{k} E R N_{t-k} \\
& +\sum_{l=1}^{r_{1}} \phi_{l} E V P_{t-l}+\sum_{m=0}^{r_{2}} \psi_{m} E V N_{t-m}+\varepsilon_{3 t}
\end{aligned}
$$

where $C_{3}, \theta_{i}(i=1,2, \ldots, p), \vartheta_{j}\left(j=0,1, \ldots, q_{1}\right), \varphi_{k}\left(k=0,1, \ldots, q_{12}\right), \phi_{l}\left(l=0,1, \ldots, r_{1}\right)$, and $\psi_{m}\left(m=0,1, \ldots, r_{2}\right)$ are the parameters of the regression equation, and $\varepsilon_{3 t}$ is the error. Equation (4) can be changed to (6), which is the ECM-NARDL model.

$$
\begin{aligned}
D\left(S T P_{t}\right)= & \vartheta_{0} D\left(E R P_{t}\right)+\varphi_{0} D\left(E R N_{t}\right)+\phi_{0} D\left(E V P_{t}\right)+\psi_{0} D\left(E V N_{t}\right)+\Pi_{2} E C_{2(t-1)} \\
& +\sum_{i=1}^{p-1} \theta_{i}{ }^{*} D\left(S T P_{t-i}\right)+\sum_{j=1}^{q_{1}-1} \vartheta_{j}{ }^{*} E R P_{t-j}+\sum_{k=1}^{q_{2}-1} \varphi_{k}{ }^{*} D\left(E R N_{t-k}\right) \\
& +\sum_{l=1}^{r_{1}-1} \phi_{l}{ }^{*} D\left(E V P_{t-l}\right)+\sum_{m=1}^{r_{2}-1} \psi_{j}{ }^{*} D\left(E V N_{t-m}\right)+\varepsilon_{3 t}
\end{aligned}
$$

where $\vartheta_{0}, \varphi_{0}, \phi_{0}, \psi_{0}, \theta_{i}{ }^{*}, \vartheta_{j}{ }^{*}, \varphi_{k}{ }^{*}, \phi_{l}{ }^{*}$ and $\psi_{j}{ }^{*}$ are variable or short term coefficients. The short term asymmetric effect occurs in case $\vartheta_{0} \neq \varphi_{0} \mathrm{dan} \vartheta_{j}{ }^{*} \neq \varphi_{k}{ }^{*}, \phi_{0} \neq \psi_{0}$ and $\phi_{l}{ }^{*} \neq \psi_{j}{ }^{*}$. The coefficient $\Pi_{2}$ is called the error correction coefficient. $E C_{2(t-1)}$ in equation (6) satisfies the equation (7)

$$
\begin{aligned}
E C_{2(t-1)} & =S T P_{t-1}-\frac{\sum_{j=0}^{q_{1}} \vartheta_{j}}{1-\sum_{i=1}^{p} \theta_{i}} E R P_{t-1}-\frac{\sum_{k=0}^{q_{2}} \varphi_{k}}{1-\sum_{i=1}^{p} \theta_{i}} E R N_{t-1}-\frac{\sum_{l=0}^{r_{1}} \phi_{l}}{1-\sum_{i=1}^{p} \theta_{i}} E V P_{t-1} \\
- & \frac{\sum_{m=0}^{r_{2}} \psi_{m}}{1-\sum_{i=1}^{p} \theta_{i}} E V N_{t-1}-\frac{C_{3}}{1-\sum_{i=1}^{p} \alpha_{i}},
\end{aligned}
$$

where $\left(\frac{\sum_{j=0}^{q_{1}} \vartheta_{j}}{1-\sum_{i=1}^{p} \theta_{i}}, \frac{\sum_{k=0}^{q_{2}} \varphi_{k}}{1-\sum_{i=1}^{p} \theta_{i}}, \frac{\sum_{l=0}^{r_{1}} \phi_{l}}{1-\sum_{i=1}^{p} \theta_{i}}, \frac{\sum_{m=0}^{r_{2}} \psi_{m}}{1-\sum_{i=1}^{p} \theta_{i}}\right)$ is the cointegration vector or the long term multiplier vector of the asymmetric effect of ERP, ERN, EVP and EVN variables on STP if these four variables are cointegrated or time series $R E S_{2}=E C_{2}$ in equation (7) is stationary at level. The long term asymmetric effects of exchange rate and exchange rate volatility on stock prices occur in case $\frac{\sum_{j=0}^{q_{1}} \vartheta_{j}}{1-\sum_{i=1}^{p} \theta_{i}} \neq \frac{\sum_{k=0}^{q_{2}} \varphi_{k}}{1-\sum_{i=1}^{p} \theta_{i}}, \frac{\sum_{l=0}^{r_{1}} \phi_{l}}{1-\sum_{i=1}^{p} \theta_{i}} \neq \frac{\sum_{m=0}^{r_{2}} \psi_{m}}{1-\sum_{i=1}^{p} \theta_{i}}$. The testing procedure of the significance of the NARDL model's parameters is similar to that of the linear ARDL model. 


\section{RESULTS AND DISCUSSION 4.1. Results}

Table 2 indicates the likely outcomes of the ADF and PP tests projected outcomes. Alltime series of variables, including the IDR/USD exchange rate and volatility, the partial sum of positive and negative changes in IDR/USD exchange rate and volatility, and stock price are stationary at first difference or process I(1).

Table 2: Unit Root Test

\begin{tabular}{lcccc}
\hline Variable & \multicolumn{2}{c}{ ADF Test Statistics } & \multicolumn{2}{c}{ PP Test Statistics } \\
\cline { 2 - 5 } & Constant & $\begin{array}{c}\text { Constant and } \\
\text { Linear Trend }\end{array}$ & Constant & $\begin{array}{c}\text { Constant and } \\
\text { Linear Trend }\end{array}$ \\
\hline EXR & -0.579919 & -2.085768 & -0.680336 & -2.268168 \\
D(EXR) & $-11.58400^{*}$ & $-11.55846^{*}$ & $-11.57453^{*}$ & $-11.54721^{*}$ \\
EXV & -5.203340 & -5.266204 & -5.203152 & -5.272139 \\
D(EXV) & $-14.67729^{*}$ & $-14.63171^{*}$ & $-24.38246^{*}$ & $-24.38626^{*}$ \\
STP & -1.952148 & -2.845072 & -1.885498 & -2.731696 \\
D(STP) & $-9.760884^{*}$ & $-9.800091^{*}$ & $-9.826386^{*}$ & $-9.859287^{*}$ \\
ERP & -0.946830 & -2.182563 & -0.844601 & -2.148863 \\
D(ERP) & $-8.749410^{*}$ & $-8.755537^{*}$ & $-8.876080^{*}$ & $-8.878190^{*}$ \\
ERN & -1.983364 & -1.320811 & -1.736594 & -1.555538 \\
D(ERN) & $-11.97093^{*}$ & $-12.14121^{*}$ & $-12.31584^{*}$ & $-12.36917^{*}$ \\
EVP & -0.721262 & -2.478257 & -0.723569 & -2.514418 \\
D(EVP) & $-12.39876^{*}$ & $-12.37352^{*}$ & $-12.41605^{*}$ & $-12.39036^{*}$ \\
EVN & -0.656475 & -2.278403 & -0.631523 & -2.238779 \\
D(EVN) & $-6.595082^{*}$ & $-6.585193^{*}$ & $-11.97802^{*}$ & $-11.95885^{*}$ \\
\hline
\end{tabular}

Note: * significant at $1 \%$ level. Source: Own processing

Table 3 summarized the result of the Engle-Granger and the Phillips-Ouliaris cointegration tests. Since the $R E S_{1}$ and $R E S_{2}$ variables are not stationary at level, the hypothesis $H_{O}$ from the cointegration test is accepted. This means no cointegration exists between the IDR/USD exchange rate, its volatility and stock price. Similarly, the partial sums of positive and negative changes in IDR/USD exchange rates and exchange rate volatility, and stock price are not cointegrated. The cointegration test show no symmetric and asymmetric IDR/USD exchange rate and volatility influence on stock price in the long term.

Table 3: The Engle-Granger and Phillips-Ouliaris Tests for Cointegration

\begin{tabular}{lcccc}
\hline \multirow{2}{*}{ Variable } & \multicolumn{2}{c}{ Engle-Granger Test/ADF Test Statistics } & \multicolumn{2}{c}{$\begin{array}{c}\text { Phillips-Ouliaris Test/PP Test } \\
\text { Statistics }\end{array}$} \\
\cline { 2 - 5 } & Constant & $\begin{array}{c}\text { Constant and } \\
\text { Linear Trend }\end{array}$ & Constant & $\begin{array}{c}\text { Constant and } \\
\text { Linear Trend }\end{array}$ \\
\hline$R E S_{1}$ & $-2.202746^{*}$ & $-3.131414^{*}$ & $-3.739646^{*}$ & $-2.988071^{*}$ \\
$R E S_{2}$ & $-3.212365^{*}$ & $-3.751675^{*}$ & $-4.053339^{*}$ & $-4.755535^{*}$ \\
\hline Note: ${ }^{*}$ mean insignificant (or the null hypothesis of cointegration test is accepted). &
\end{tabular}

To test the short term symmetric and asymmetric influence of the IDR/USD exchange rate and the IDR/USD volatility on stock prices, the ARDL and the NARDL in the first difference was estimated. The length of the time lag based on the Akaike Information Criterion (AIC). Based on this criterion, the $\operatorname{ARDL}(3,3,0)$ and the $\operatorname{NARDL}(1,0,0,0,1)$ models were obtained. Table 4 shows all statistical values related to the estimation of the $\operatorname{ARDL}(3,3,0)$ and the $\operatorname{NARDL}(1,0,0$, $0,1)$.

Table 4: ARDL and NARDL Estimation 


\begin{tabular}{lrrr}
\hline Independent Variable & Coefficient & $\begin{array}{c}\text { t-statistic or } \\
\chi^{2} \text {-statistic }\end{array}$ & Probability \\
\hline A. ARDL (3,3,0) Model. Dependent Variable: D(STP) & & & \\
D(STP (-1)) & $0.1777^{* *}$ & 2.0913 & 0.0382 \\
D(STP(-2)) & 0.0706 & 0.8525 & 0.3953 \\
D(STP(-3)) & $0.1911^{* *}$ & 2.3197 & 0.0217 \\
D(EXR) & $-1.2904^{*}$ & -8.9267 & 0.0000 \\
D(EXR(-1)) & 0.2428 & 1.4019 & 0.1630 \\
D(EXR(-2)) & 0.1115 & 0.6404 & 0.5229 \\
D(EXR(-3)) & $0.3487^{* *}$ & 2.0461 & 0.0425 \\
D(EXV) & 0.4252 & 1.5169 & 0.1314 \\
Breusch-Godfrey Serial Correlation LM & & 0.0269 & 0.9866 \\
Test & & & 0.0565 \\
Heteroscedasticity ARCH Test & & & \\
\hline B. NARDL(1, 0, 0, 0, 1) model. Dependent Variable: D(STP) & & \\
D(STP(-1)) & $0.1181^{* * *}$ & 1.8406 & 0.0676 \\
D(ERP) & $-1.7186^{*}$ & -8.6199 & 0.0000 \\
D(ERN) & $-0.9673^{*}$ & -4.1895 & 0.0000 \\
D(EVP) & $1.4278^{*}$ & 3.9788 & 0.0001 \\
D(EVN) & $-1.4317^{*}$ & -2.8609 & 0.0048 \\
D(EVN(-1)) & $-0.8645^{* * *}$ & -1.8077 & 0.0726 \\
Breusch-Godfrey Serial Correlation LM Test & & 1.2621 & 0.5320 \\
Heteroscedasticity ARCH Test & & 2.1667 & 0.1410 \\
\hline
\end{tabular}

Note: sign $*, * *$ or $* * *$ means significant at significant level $1 \%, 5 \%$ or $10 \%$.

Table 4 in Panel A shows that the coefficients of the variables D(EXR) and D (EXR(-3)) are significant at $1 \%$ and $5 \%$, respectively, though $\mathrm{D}(\mathrm{EXV})$ is insignificant. This means that a symmetric effect of the IDR/USD on stock prices exists. There is no symmetric effect of IDR/USD exchange rate volatility. This conclusion is valid because the $\operatorname{ARDL}(3,3,0)$ model residual is homoscedastic and does not have autocorrelation.

The coefficients of the variables $\mathrm{D}(\mathrm{ERP}), \mathrm{D}(\mathrm{ERN}), \mathrm{D}(\mathrm{EVP}), \mathrm{D}(\mathrm{EVN})$, and $\mathrm{D}(\mathrm{EVN}(-1))$ are significant at $1 \%$, and the coefficient variable $\mathrm{D}(\mathrm{EVN}(-1))$ is $10 \%$ significant with different coefficients (see Panel B of Table 4). Since the coefficient D(ERN) is negative, the Indonesian currency exchange rate's appreciation against the United States currency negatively affects the stock prices. This indicates asymmetric effects of both the IDR/USD exchange rate and volatility. Since the NARDL $(1,0,0,0,1)$ model residual is homoscedastic and has no autocorrelation, this conclusion is valid.

The exchange rate's symmetric and asymmetric effect of exchange rate and volatility on stock prices is robust. The coefficients of exchange rate, volatility, and the partial sum of positive and negative changes are significant at $1 \%$.

\subsection{Discussion}

Exchange rate symmetrically affect stock prices. Precisely, the domestic exchange rate appreciation negatively impacts stock prices. However, this finding is short term in nature. Theoretically, it is in line with the theory put forward by Ma and Kao (1990), in which Indonesia's trade balance rose yearly from 2006 t02018 (FRBSL, 2019). This means that exports were more dominant than imports. Furthermore, this finding is empirically in line with Ozbey et al. (2016), Gong and Dai (2017), and Zarei et al. (2019). There is also no symmetric effect of volatility, a finding which contradicts Obegue (2012), Mlambo et al. (2013), Parera (2016), Sichoongwe 
(2016), Najafzadeh et al. (2016), and Mhari and Dadoui (2017). Economic and socio-political conditions and the cultural characteristics of the countries researched may account for varied results (Ozturk, 2010). Variation in time-series data analyzed may also explain this condition (Novita and Nachrowi, 2005; Adam et al., 2015). Furthermore, such a difference can be caused by the analysis method. For example, Najafzadeh et al. (2016) used panel data model analysis in which the conclusions apply to several countries altogether. However, this study utilizes a different analysis since it only focuses on a single country, Indonesia.

No long term symmetric or asymmetric effect of both the exchange rate and volatility is found. The absence of long term effect may be attributed to the dominant impact of the prevailing market mechanisms, such as supply and demand factors (Suriani et al., 2015).

This research recommends that the Indonesian government continue implementing and developing monetary policy to appreciate the IDR currency under control. Consequently, the stock prices listed on the ISE will increase, encouraging investors to invest in the stock market.

\section{CONCLUSION}

This research examined the symmetric and asymmetric impact of IDR/USD exchange rate and volatility using monthly time series data from January 2006 to July 2019 of the exchange rate and the composite stock price index. The ARDL and NARDL models determined the IDR/USD exchange rate's symmetric and asymmetric effects as well as the volatility on stock prices.

According to results, the IDR/USD rate influence stock prices in the short run symmetrical, different from volatility. However, these two variables asymmetrically affect stock prices, though they lack either a symmetric and an asymmetric influence in the long run.

\section{REFERENCES}

Adam, P., Rianse, U., Cahyono, E., \& Rahim, M. (2015). Modeling of the Dynamics Relationship between World Crude Oil Prices and the Stock Market in Indonesia. International Journal of Energy Economics and Policy, Vol. 5, No. 2, pp. 550-557.

Adam, P., Rosnawintang., Nusantara, A. W., \& Muthalib, A. A. (2017). A Model of the Dynamic of the Relationship between Exchange Rate and Indonesia's Export. International Journal of Economics and Financial Issues, Vol. 7, No. 1, pp. 255-261.

Bag, T., Azad, T., Razzaq, S., Liaqat, I., \& Khan, M. A. (2017). The Impact of Exchange Rate Volatility on Stock Index: Evidence from Pakistan Stock Exchange (PSX). International Journal of Academic Research in Accounting, Finance and Management Sciences, Vol. 7, No. 3, 70-86. https://doi.org/10.6007/IJARAFMS/v7-i3/3150

Bahmani-Oskooee, M ., \& Saha, S. (2016). Do Exchange Rate Changes have Symmetric or Asymmetric Effects on Stock Prices?. Global Finance Journal, Vo. xxx, pp. 1-16. https://doi.org/10.1016/j.gfj.2016.06.005

Bahmani-Oskooee , M., \& Xi . (2015). Exchange Rate Volatility and Domestic Consumption: Evidence from Japan. Economic Systems, Vol. 36, pp. 326-335. https://doi.org/10.1016/j.ecosys.2011.10.004 
Chang, E. C., Cheng, J. W., \& Khorana, A. (2000). An Examination of Herd Behavior in Equity Markets: An International Perspective. Journal of Banking and Finance, Vol. 24, No. 10, pp. 1651-1679. https://doi.org/10.1016/S0378-4266(99)00096-5

Dickey, D. A., \& Fuller, W. A. (1979). Distribution of the Estimators for Autoregressive Time Series with a Unit Root. Journal of the American Statistical Assosiation, Vol. 74, pp. 427-443. https://doi.org/10.2307/2286348

Dornbusch, R., \& S. Fischer. (1980). Exchange Rates and the Current Account. The American Economic Review, Vol. 70, No. 5, pp. 960-971.

Engle, R. F., \& Granger, C. W. J. (1987). Co-integration and Error Correction: Representation, Estimation, and Testing. Econometrica, Vol. 55, pp. 251-276. https://doi.org/10.2307/1913236

FRBSL(Federal Research Bank of St Louist). (2019). Fred Economic Data. Washington, USA: Federal Research Bank of St Louist.

Gong, P., \& Dai, J. (2017). Monetary Policy, Exchange Rate Fluctuation, and Herding Behavior in the Stock Market. Journal of Business Research, Vol. 76, pp. 34-43. https://doi.org/10.1016/j.jbusres.2017.02.018

Heij, C., Boer, P., Frances, P. H., Kloek, T., \& Dijk, H. K. (2004). Econometric Methods with Application in Business and Economics. Clareendon : Oxford University Press.

Lukman, R., \& Kouser, R. (2015). Asymmetrical Linkages between Foreign Exchange and Stock Markets: Empirical Evidence through Linear and Non-Linear ARDL. Journal of Risk and Financial Management, Vol. 6, No. 51, pp. 1-14.

Ma, C., \& Kao, G. W. (1990). On Exchange Rate Changes and Stock Price Reactions. Journal of Business Finance and Accounting, Vol.17, No. 3, pp. https://doi.org/10.1111/j.1468-5957.1990.tb01196.x

Malliaropulos, D. (1998). International Stock Return Differentials and Real Exchange Rate Changes. Journal of International Money and Finance, Vol. 17, pp. 493-511. https://doi.org/10.1016/S0261-5606(98)00013-8

Mgammal, M. H. H. (2012). The Effect of Inflation, Interest Rates and Exchange Rates on Stock Prices Comparative Study Among Two GCC Countries. International Journal of Finance and Accounting, Vol. 1, No. 6, pp. 179-189.

Misra, P. (2018). An Investigation of the Macroeconomic Factors Affecting the Indian Stock Market. Australasian Accounting, Business and Finance Journal, Vol. 12, No. 2, pp. 71-86. https://doi.org/10.14453/aabfj.v12i2.5

Mlambo, C., Maredza, A., \& Sibanda, S. (2013).Effects of Exchange Rate Volatility on the Stock Market: A Case Study of South Africa.Mediterranean Journal of Social Sciences, Vol. 4, No. 14, pp. 561-570. https://doi.org/10.5901/mjss.2013.v4n14p561 
Saidi, Muthalib, Adam, Rumbia \& Sani | Exchange Rate, Exchange Rate Volatility and Stock Prices

Mrhari, E. M., \& Daoui, D. (2017). Analysis of the Exchange Rate Volatility Influence on the Share Price: Morocco, as Case Study. Journal of Public Administration, Finance and Law,Vol. 12, pp. 114-127.

Najafzadeh, B., Monjazeb, M., \&Mamipour, S. (2015). The Analysis of Real Exchange Rate Volatility and Stock Exchange Return with PANEL-GARCH Approach (Case Study: D8 Countries). Iranian Economic Review, Vol. 20, No. 4, pp. 525-550.

Novita, M., \& Nachrowi, N. D. (2005). Dynamic Analysis of Stock Price Index and Exchange Rate Using Vector Autoregression (VAR) Empirical Study in JSX, 2001-2004. Economic and Finance in Indonesia, Vol. 53, No. 3, pp. 263-278. https://doi.org/10.7454/efi.v53i3.134

Olugbenga, A. A. (2012). Exchange Rate Volatility and Stock Market Behaviour: The Nigerian Experience. European Journal of Business and Management, Vol. 4, No. 5, pp. 31-39.

Ozbey, F., Iscan, E., \& Tras, M. F. (2016). Ho do Exchange Rate Movements Affect Stock Prices? The Case of Turkey. Proceeding of 22nd International Academic Conference 3506112, International. Extracted from https://www.iises.net/proceedings/22nd-international-academic-conference-lisbon/table-ofcontent. https://doi.org/10.20472/IAC.2016.022.040

Ozturk, I. (2010). A literature Survey on Energy-Growth Nexus. Energy Policy, Vol. 38, pp. 340-34.9. https://doi.org/10.1016/j.enpol.2009.09.024

Perera H. A. P. K. (2016). Effects of Exchange Rate Volatility on Stock Market Return Volatility: Evidence from an Emerging Market. International Journal of Science and Research, Vol. 5, No. 1, pp. 17501755. https://doi.org/10.21275/v5i1.NOV153206

Pesaran, M. H., \& Shin, Y. (1999). An Autoregressive Distributed-Lag Modelling Approach to Cointegration Analysis, InS. Strom (Eds.), Econometrics and Economic Theory in the 20th Century: The Ragnar Frisch Centennial Symposium (371-413).Cambridge: Cambridge University Press. https://doi.org/10.1017/CCOL521633230.011

Phillips, P. C. B., \& Ouliaris, S. (1990). Asymptotic Properties of Residual Based Tests for Cointegration. Econometrica, Vol. 58, No. 1, pp. 165-93. https://doi.org/10.2307/2938339

Phillips., P. C. B., \& Perron, P. (1988). Testing for a Unit Root in Time Series Regression. Biometrika, Vol. 75, No. 2, pp. 335-346. https://doi.org/10.1093/biomet/75.2.335

Saidi, L. D., Kamaluddin, M., Rostin., Adam, P., \& Cahyono, E. (2015). The Effect of the Interaction between US Dollar and Euro Exchange Rates on Indonesia's Nasional Income. Wseas Transactions on Business and Economics, Vol. 12, pp. 131-137.

Saman, C. (2015). Asymmetric Interaction between Stock Price Index and Exchange Rates: Empirical evidence for Romania. Romanian Journal of Economic Forecasting, Vol. 18, No. 4, pp. 90-109.

Shin, Y., Yu, B. C., and Greenwood-Nimmo, M. (2014). Modelling Asymmetric Cointegration and Dynamic Multipliers in a Nonlinear ARDL Framework in Sickels, R. and Horrace, W. (Eds), Festschrift in Honor of Peter Schmidt: Econometric Methods and Applications ( 81-314). New York, NY: Springer. https://doi.org/10.1007/978-1-4899-8008-3_9 
AABFJ | Volume 15, No.4, 2021

Sichoongwe, K. (2016). Effects of Exchange Rate Volatility on the Stock Market: The Zambian Experience. Journal of Economics and Sustainable Development, Vol. 7, No. 4, pp. 114-119.

Suriani, S., Kumar, M. D., Jamil, F., \& Muneer, S. (2015). Impact of Exchange Rate on Stock Market. International Journal of Economics and Financial Issues, Vol. 5 (Special Issue), pp. 385-388.

Wagner, H. (2019). Why Volatility is Important For Investors. Ectracted from https://www.investopedia.com/articles/financial-theory/08/volatility.asp

Zarei, A., Ariff, M., \& Bhatti, I. (2019). The Impact of Exchange Rates on Stock Market Returns: New Evidence from Seven Free-Floating Currencies. The European Journal of Finance, Vol. 25, No. 14, pp. 12771288. https://doi.org/10.1080/1351847X.2019.1589550 